\title{
Functional diversity, soil features and community functioning: a test in a cerrado site
}

\author{
Freitas, JR. ${ }^{a *}$, Cianciaruso, $M V^{b}$ and Batalha, MA. ${ }^{a}$ \\ ${ }^{a}$ Department of Botany, Federal University of São Carlos - UFSCar, CP 676, CEP 13565-905, São Carlos, SP, Brazil \\ ${ }^{b}$ Department of Ecology, Federal University of Goiás - UFG, CP 131, CEP 74001-970, Goiânia, GO, Brazil \\ *e-mail: juzinhabio@gmail.com \\ Received July 1, 2011 - Accepted October 6, 2011 - Distributed August 31, 2012
}

\begin{abstract}
Community functioning may be affected by functional diversity, which measures the extent of complementarity in resource use. We tested whether there was a relationship between functional diversity of woody species and community functioning on a fine scale, using FD as a measure of functional diversity and litter decomposition rate as a surrogate for community functioning. We measured eight functional traits from a woodland cerrado community in southeastern Brazil. Then, we tested the correlation between FD and the decomposition rate taking into account differences in soil features and between decomposition rate and each trait separately. The decomposition rate was related to the aluminium and phosphorus concentration in soil, but not to FD, pointing out that functional diversity was not a good predictor of community functioning. There was a non-significant relationship between FD and the decomposition rate even when we considered each trait separately. Most studies in the relationships between biodiversity and community functioning on fine scales were carried out by experimental manipulation of diversity and in temperate regions. We carried out this fine scale study as a mensurative experiment and in a tropical savanna. Our findings indicated that the relationship between biodiversity and community functioning is not as straightforward as usually assumed.
\end{abstract}

Keywords: litter decomposition, nutrient cycling, savanna, woodland cerrado.

\section{Diversidade funcional, características edáficas e funcionamento de comunidade: teste em um sítio de cerrado}

\begin{abstract}
Resumo
O funcionamento das comunidades deve ser afetado pela diversidade funcional, uma vez que esta mede a extensão da complementaridade no uso de recursos. Testamos se havia relação entre diversidade funcional das espécies arbóreas e o funcionamento da comunidade em escala fina, usando a FD como medida de diversidade funcional e a taxa de decomposição da serapilheira como indicadora do funcionamento. Medimos oito traços funcionais de plantas arbóreas em uma comunidade de cerrado no sudeste do Brasil. Testamos a correlação entre a FD e as taxas de decomposição, considerando diferenças nas variáveis edáficas e entre as taxas de decomposição e cada traço, separadamente. As taxas de decomposição se mostraram relacionadas com as concentrações de alumínio e fósforo, e não com a FD, indicando que a diversidade funcional não é uma boa preditora do funcionamento da comunidade. Não houve relação significativa entre FD e decomposição, mesmo quando consideramos cada traço separadamente. A maioria dos estudos sobre a relação entre diversidade e funcionamento em escalas finas foi desenvolvida por meio da manipulação experimental da diversidade e em regiões temperadas. Nossos resultados indicaram que a relação entre biodiversidade e funcionamento das comunidades não é tão direta como se assume usualmente.
\end{abstract}

Palavras-chave: decomposição de serapilheira, ciclagem de nutrientes, savana, Cerrado sensu stricto. 


\section{Introduction}

Biological diversity may affect community functioning by the role of each species in a given community (Díaz and Cabido, 2001). At first, studies concerning the relationship between diversity and community functioning used species richness as a measure of diversity (Naeen et al., 1994). However, this measure implicitly assumes that all species are equally different and, consequently, the addition of any species to a community should increase the functioning by one unit (Petchey et al., 2004). Recently, the consensus that species contribution to the processes is different has been growing (Hooper et al., 2005). Species richness has been viewed as a measure that incorporates little or no information about individual species and, thus, explains and predicts poorly (Hooper et al., 2002; 2005; Petchey et al., 2004; Petchey and Gaston, 2006). Community functioning must be determined by the value and range of species functional traits, that is, characteristics that affect the organism fitness through direct or indirect effects on growth, reproduction, and survival (Díaz and Cabido, 2001; Hooper et al., 2005; Petchey and Gaston, 2002). The functional approach is closely related to the niche models, in which separation in niche space allows coexistence through a lack of competition for similar resources and, thus, leads to greater complementarity (MacArthur, 1972). Since an increase in functional diversity should be related to an increase in the intensity of the processes in community functioning, functional diversity is expected to be a good predictor of functioning (Petchey and Gaston, 2002).

Community functioning is defined as the flow of matter and energy through the arrangement of biotic and abiotic components of the communities (Díaz and Cabido, 2001). Since decomposition is a process closely related to nutrient cycling (Swift et al., 1979), it can be used as a surrogate for community functioning. Litter decomposition may be affected by plant diversity through two mechanisms: directly, through changes in litter species composition, and indirectly, by altering the decomposition microenvironment (Madritch and Cardinale, 2007; Vivanco and Austin, 2008). Litters of different architecture may complement one another by providing more favourable physical living space, because the resulting pockets may encourage microbial growth and macroinvertebrate fauna invasion (Hansen, 2000). Plant species can also determine the litter macroinvertebrate community and decomposition process below their canopies (Negrete-Yankelevich et al., 2008). Moreover, different species of plants may create specific conditions that increase the breakdown of their own litter, establishing affinity effects between species and their microenvironment (Vivanco and Austin, 2008). Thus, plant species produce conditions in their environment that affect the processes of decomposition.

Up to now, most studies that addressed the effect of diversity upon decomposition used traditional measures, such as species richness (for example, Negrete-Yankelevich et al., 2008; Vivanco and Austin, 2008). In these cases, diversity effects could only arise if species differed in relevant functional characteristics to the studied process. If so, species richness and other diversity measures could be useful proxies of functional diversity in a community (Gessner, 2010). However, direct functional characterisations of communities, such as functional trait distributions including dissimilarity patterns, are likely to be more compelling predictors of the effect of diversity upon litter decomposition. Indeed, recent studies that analysed species richness, number of functional groups, and functional composition suggested that the functional approach tends to be more predictive (Petchey et al., 2004; Ricotta, 2005; Scherer-Lorenzen, 2008).

Many studies that applied the functional approach used the number of functional groups in a community as a diversity measure (for example, Denyer et al., 2010; McLaren and Turkington, 2010; Scherber et al., 2010). Of the problems associated with assigning species to groups, perhaps the least tractable is the arbitrary scale at which differences among species qualify as functionally significant (Petchey and Gaston, 2002). Here, we used a broadly accepted, continuous measure of functional diversity, FD (Petchey and Gaston, 2002). To calculate FD, one may use the functional trait values and construct a dendrogram based on the differences among species (Petchey and Gaston, $2002 ; 2006)$. The sum of the branches necessary to connect all species in the community is FD (Petchey and Gaston, 2002). The more different the functional trait values, the higher the sum of the branches and, thus, the higher the FD (Petchey and Gaston, 2002; 2006). As long as litter decomposition can be used as a surrogate for community functioning, we expected that sites with higher FD values should present higher litter decomposition rates.

In larger-scale patterns, functioning and diversity are both covarying with environmental factors that change from place to place (Loreau, 1998; Loreau and Hector, 2001), because on such a scale physical processes may dominate or dissipate biological effects (Wiens, 1989). We developed our study on a local scale (sensu Leibold et al., 2004), in which the influence of diversity on community functioning will depend rather on the traits of the species present and their ecological interactions than on direct physical determination (Wiens, 1989). Although many authors suggested a relationship between functional diversity and community functioning (Díaz and Cabido, 2001; Hooper et al., 2005; Tilman et al., 1997), there are few studies focused on testing it (Scherer-Lorenzen, 2008), especially in tropical regions. The Brazilian cerrado presents a seasonal climate with a dry winter and wet summer. The occurrence of the cerrado and its physiognomic variation are considered by some authors to be a fertility gradient (Goodland and Pollard, 1973). Both the decomposition process and floristic composition may be affected by abiotic variables and, in particular, soil features play an important role (Swift et al., 1979). On the one hand, since we carried out this study on a fine scale, climate and fire frequency were homogeneous. On the other hand, since changes in soil features may be found at distances as small as $1 \mathrm{~m}$ (Souza and Martins, 2004), soil is an important candidate 
to exert effects upon vegetation and decomposition process on such a scale.

Moreover, there is a lack of information concerning the relative importance of different traits for different community functions (Petchey and Gaston, 2002). Perhaps some traits could show greater differences among species and others, less. Taking this into account, including traits that present small differences could dilute differences among species and reduce the value of FD, masking a possible relationship between FD and decomposition. To avoid this problem, we also tested whether each trait separately was related to decomposition rate. In total, we tested the relationship between functional diversity and community functioning in a southern cerrado site, by sampling woody species on a fine scale and using a litter decomposition rate as a surrogate for community functioning. We addressed the following questions: (1) is the FD related to the decomposition rate taking soil features into account? (2) when analysing functional traits separately, are they related to the decomposition rate?

\section{Material and Methods}

We carried out this study in a woodland cerrado site located at the Federal University of São Carlos, southeastern Brazil (approximately, $21^{\circ} 58^{\prime} 05^{\prime} \mathrm{S}$ and $47^{\circ} 52^{\prime} 10^{\prime} \mathrm{W}$, $872 \mathrm{~m}$ a.s.1.). The regional climate is seasonal, with dry winters and wet summers, defined as Cwa (Köppen, 1931). We established a $50 \mathrm{~m} \times 50 \mathrm{~m}$ grid, in which we placed 100 contiguous $25 \mathrm{~m}^{2}$ plots. We sampled all individuals belonging to the woody component, defined as those with a stem diameter at a soil level equal to or higher than $3 \mathrm{~cm}$ (São Paulo, 1997), which we identified as the species level. For each individual, we measured eight functional traits related to community functioning: leaf size, specific leaf area, leaf dry matter content, stem specific density, height, basal area, resprouting capacity, and bark thickness (Cornelissen et al., 2003; see Table 1).

For leaf size, leaf specific area and leaf dry matter content, we collected five undamaged, fully expanded leaves from each individual during the morning until 10:00 AM. (Cornelissen et al., 2003). We kept the leaves in plastic bags and stored them in a cooler to avoid water loss or deterioration. In the laboratory, we measured fresh mass, scanned the leaves, and calculated the leaf sizes with ImageJ 1.33 (Rasband, 2004). Then, we oven-dried the leaves at $80{ }^{\circ} \mathrm{C}$ for 72 hours and measured the dry mass. We divided the leaf size by dry mass to find the specific leaf area. We also divided the dry mass from the fresh mass to find dry matter content. Stem specific density is the dry mass of a section of the main stem divided by its volume (Cornelissen et al., 2003). We cut $10 \mathrm{~cm}$ long sections of the stems, removed the bark, and placed the sections in plastic bags. In the laboratory, we estimated the volume, by immersing them in water for 5 seconds in volumetric flasks and measuring the increase in volume (Cornelissen et al., 2003). Next, we oven-dried them at $80{ }^{\circ} \mathrm{C}$ for 72 hours and weighed them. Using a telescopic ruler, we measured height, the shortest distance between the upper boundary of the main photosynthetic tissues and the soil level (Cornelissen et al., 2003). We calculated the basal area by measuring the stem perimeter at soil level. We measured the resprouting capacity by counting branches at the base of the trunk. We removed a portion of the stem at $30 \mathrm{~cm}$ high with a knife and measured the bark thickness with a digital caliper.

We collected leaves recently shed, oven-dried them at $80{ }^{\circ} \mathrm{C}$ for 24 hours, and put $5 \mathrm{~g}$ in each of the 2,000 litterbags. In each plot, we placed four sets of five litterbags, that is, 20 litterbags per plot. We collected four bags from each set in each plot after 1, 2, 3, 6, and 12 months. In the laboratory, we gently brushed the material to remove soil particles and other debris, oven-dried the bags at $80{ }^{\circ} \mathrm{C}$ for 24 hours, and weighed them. Comparing the initial and the final masses, we found the amount of litter that was decomposed. For each plot and each month, thus, we found the average remaining amount of matter. The exponential model is the best descriptor of mass loss during decomposition (Wieder and Lang, 1982). Therefore, we adjusted the values to an exponential equation $\left(\mathrm{y}=\mathrm{ae}^{-\mathrm{kt}}\right)$, in which $y$ is the portion of the remaining mass at time $\mathrm{t}$ (in months), $\mathrm{a}$ is the initial mass, and $\mathrm{k}$ is the rate of decomposition. We used soil data collected in the same plots (Dantas and Batalha, 2011) and selected pH, organic matter, available phosphorus, total nitrogen, sum of bases, base saturation, aluminium saturation, and sand, silt, and clay proportions.

We calculated the FD for each plot, following the method described by Petchey and Gaston (2002, 2006): (1) we obtained a trait matrix with species in rows, functional traits in columns, and average trait values in entries; (2) after standardising the trait matrix to the zero mean and unit variance, we transformed it into a distance matrix, using Euclidean distance; (3) we used the distance matrix to produce a dendrogram with the unweighed pair-group clustering method using arithmetic averages; and (4) we calculated the total branch length of the dendrogram necessary to connect all species in a given plot. To check whether the dendrogram was describing the structure of the distance matrix appropriately, we calculated the cophenetic correlation coefficient (Petchey and Gaston, 2002, 2006).

To answer the first question, we did a multiple linear regression analysis, using a decomposition rate as a response variable and both FD and soil features (ph, organic matter, total nitrogen, available phosphorus, exchangeable aluminium, sum of bases, base saturation, sand proportion, and clay proportion) as explanatory variables. We selected the best model, using the Akaike Information Criterion, which considers the complexity of an estimated model and how efficient this model is in fitting the data (McNeil et al., 1996). We compared the models based on $\triangle \mathrm{AIC}_{\mathrm{c}}, \mathrm{AIC}_{\mathrm{c}} \mathrm{w}_{\mathrm{i}}$, and the coefficient of determination (Burnham and Anderson, 2002). $\triangle \mathrm{AIC}_{\mathrm{c}}$ is the difference between each model's $\mathrm{AIC}_{\mathrm{c}}$ and the minimum $\mathrm{AIC}_{\mathrm{c}}$ found. $\triangle \mathrm{AIC}_{\mathrm{c}}$ values higher than seven indicate models that have a poor fit relative to the "best" model, whereas values lower than two indicate models that 
Table 1. Functional traits used to calculate functional diversity of woody species in a woodland cerrado (21 $58^{\prime} 05^{\prime}$ S and $47^{\circ} 52$ ' 10 ” W, São Carlos, Brazil). For more details, see Cornelissen et al. (2003).

\begin{tabular}{|c|c|c|}
\hline Trait & Measurement & Functional importance \\
\hline Leaf size & continuous measure, $\mathrm{mm}^{2}$ & $\begin{array}{l}\text { Energy and water balance, related to allometric } \\
\text { factors, environmental nutrient stress, and } \\
\text { disturbance }\end{array}$ \\
\hline Specific leaf área & continuous measure, $\mathrm{mm}^{2} \mathrm{mg}^{-1}$ & $\begin{array}{l}\text { Leaf lifespan, leaf structural defences, positively } \\
\text { correlated with potential relative growth rate or } \\
\text { mass-based maximum photossintetic rate }\end{array}$ \\
\hline $\begin{array}{l}\text { Leaf dry matter } \\
\text { contente }\end{array}$ & continuous measure, mg.g $\mathrm{g}^{-1}$ & $\begin{array}{l}\text { Related to average density of leaf tissues, } \\
\text { negatively correlated with potential relative growth } \\
\text { rate and positively correlated with leaf lifespan }\end{array}$ \\
\hline Stem specific density & continuous measure, $\mathrm{mg} \cdot \mathrm{mm}^{-3}$ & Structural strength, leaf lifespan, carbon storage \\
\hline Height & continuous measure, $\mathrm{m}$ & $\begin{array}{l}\text { Competitive vigour, whole plant fecundity, time } \\
\text { intervals plant species are given to grow between } \\
\text { disturbances, correlated with aboveground } \\
\text { biomass, rooting depth, lateral spread, and leaf size }\end{array}$ \\
\hline Basal area & continuous measure, $\mathrm{m}^{2}$ & $\begin{array}{l}\text { Space ocupation, resource uptake, and total } \\
\text { biomass }\end{array}$ \\
\hline Resprouting capacity & continuous measure, count & Structural strength and resource availability \\
\hline Bark thickness & continuous measure, $\mathrm{mm}$ & Meristem protection \\
\hline
\end{tabular}

are as suitable as the "best" model (Burnham and Anderson, 2002). $\mathrm{AIC}_{\mathrm{c}} \mathrm{w}_{\mathrm{i}}$ is the Akaike's weighing of each model, which provides extra evidence that the model is actually the best explanatory model. We use the "AICcmodavg" package of the R environment (R Development Core Team, 2010). To answer the second question, we used the average value of each trait and produced new dendrograms, with which we calculated new FD values. For each trait, we did a linear regression analysis, using the decomposition rate as the response variable. We carried out all analyses in R (R Development Core Team, 2010).

\section{Results}

We sampled 1,995 individuals, belonging to 60 species and 28 families. The commonest species were Myrsine umbellata (557 individuals) and Vochysia tucanorum (168 individuals). The rarest species were Annona crassifolia, Banisteropsis megaphylla, Davilla rugosa, Ilex cerasifolia, Miconia rubiginosa, Palicourea rigida, Rapanea guianensis, Tapirira guianensis (one individual each). The richest families were Fabaceae (with eight species), Myrtaceae (with seven species), Malpighiaceae and Melastomataceae (with four species each), and Annonaceae, Erythroxylaceae, and Rubiaceae (with three species each). Mean $( \pm \mathrm{sd})$ species number in each plot was $9.54( \pm 2.35)$. The cophenetic correlation was 0.91 , indicating that the structure of the distance matrix was preserved in the dendrogram. During the studied period, $32 \%$ of the litter was decomposed. The annual decomposition coefficient $\mathrm{k}$ was 0.36 , and the mean decomposition rate in the plots was $-0.030 \pm 0.005$.

The best model to predict the decomposition rate did not include FD as an explanatory variable. Thus, FD was not a good predictor of community functioning. The best model had aluminium and phosphorus as explanatory variables (Table 2). The relationship between aluminium and phosphorus with decomposition rates were negative and positive respectively. Considering each trait separately, we found no significant relationship (Table 3).

\section{Discussion}

In the cerrado studied, FD was not a good predictor of community functioning on a fine scale. Many authors suggested that living plant traits should be a powerful tool to predict the decomposition rate and, thus, community functioning (for example, Cornwell et al., 2008; Díaz and Cabido, 2001; Fortunel et al., 2009; Hector et al., 2000), but this assumption has rarely been tested. Functional diversity presented a significant relationship with the decomposition rate in another vegetation type and when another index was used (Rao's Quadratic Entropy (Q); Scherer-Lorenzen, 2008), but we did not find it when using FD. Comparisons between functional diversity measures based on artificial data found no correlation between Q and FD (Mouchet et al., 2010), but they were correlated when functional diversity measures were based on field data (Scherer-Lorenzen et al., 2007). We chose FD as a measure of functional diversity, because it does not violate set monotonicity as Q does (Petchey and Gaston, 2007).

Many studies concluded that functional traits of living leaves affect the decomposability of their own litterfall as a legacy (Cornelissen and Thompson, 1997; Fortunel, 2009), but these studies were carried out in temperate regions and caution should be taken when extrapolating these results to tropical communities. In this study, the 
Table 2. Values calculated for the model selection for multiple linear regression analysis, using both FD and soil features as explanatory variables and decomposition rate as response variable.

\begin{tabular}{clcccc}
\hline Model & \multicolumn{1}{c}{ Explanatory variables } & $\mathbf{R}^{2}$ & $\mathbf{A I C}_{\mathbf{c}}$ & $\Delta \mathbf{A I C}_{\mathbf{c}}$ & $\mathbf{A I C}_{\mathbf{c}} \mathbf{w}_{\mathbf{i}}$ \\
\hline 1 & $\mathrm{P}+\mathrm{Al}$ & 0.094 & -779.161 & 0.000 & 0.494 \\
2 & $\mathrm{P}+\mathrm{Al}+$ clay & 0.096 & -778.159 & 1.002 & 0.300 \\
3 & $\mathrm{P}+\mathrm{Al}+\mathrm{V}+$ clay & 0.092 & -776.583 & 2.577 & 0.136 \\
4 & $\mathrm{pH}+\mathrm{P}+\mathrm{Al}+\mathrm{V}+$ clay & 0.085 & -774.493 & 4.667 & 0.048 \\
5 & $\mathrm{pH}+\mathrm{P}+\mathrm{Al}+\mathrm{V}+$ clay + nitrogen & 0.076 & -772.212 & 6.948 & 0.015 \\
6 & $\mathrm{pH}+\mathrm{P}+\mathrm{Al}+\mathrm{V}+$ clay + nitrogen + FD & 0.066 & -769.882 & 9.278 & 0.005 \\
7 & $\mathrm{pH}+\mathrm{P}+\mathrm{Al}+\mathrm{SB}+\mathrm{V}+$ clay + nitrogen + FD & 0.056 & -767.417 & 11.744 & 0.001 \\
7 & $\mathrm{pH}+\mathrm{OM}+\mathrm{P}+\mathrm{Al}+\mathrm{SB}+\mathrm{V}+$ clay + nitrogen + FD & 0.046 & -764.896 & 14.265 & 0.000 \\
8 & $\mathrm{pH}+\mathrm{OM}+\mathrm{P}+\mathrm{Al}+\mathrm{SB}+\mathrm{V}+$ sand + clay + nitrogen + FD & 0.035 & -762.310 & 16.851 & 0.000 \\
\hline
\end{tabular}

$\mathrm{P}=$ available phosphorus, $\mathrm{Al}=$ exchangeable aluminium, clay = clay proportion, $\mathrm{V}=$ base saturation, nitrogen $=$ total nitrogen, $\mathrm{OM}=$ organic matter, $\mathrm{SB}=$ sum of bases, $\mathrm{FD}=$ functional diversity.

Table 3. Values calculated for the relationship between decomposition rates and each trait separately for woody species in a

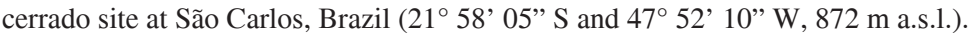

\begin{tabular}{lcccc}
\hline \multicolumn{1}{c}{ Trait } & Intercept & Slope & $\mathbf{R}_{\text {adj }}^{2}$ & P-value \\
\hline Leaf size & 0.032 & 0.001 & 0.020 & 0.160 \\
Specific leaf area & 0.030 & 0.018 & 0.001 & 0.813 \\
Leaf dry matter content & 0.028 & 0.003 & 0.002 & 0.659 \\
Leaf dry matter content & 0.028 & 0.003 & 0.002 & 0.659 \\
Stem specific density & 0.030 & 0.078 & 0.002 & 0.634 \\
Height & 0.029 & 0.001 & 0.006 & 0.451 \\
Basal area & 0.030 & 0.084 & 0.001 & 0.718 \\
Resprouting capacity & 0.030 & 0.001 & 0.002 & 0.673 \\
Bark thickness & 0.033 & 0.002 & 0.020 & 0.164 \\
\hline
\end{tabular}

cerrado dynamics did not fit this framework. Litter of high quality could be expected to enhance decomposition of other litters, whereas litter of poor quality would have negative effects (Seastadt, 1984). In poor soil environments, such as the cerrado, plants tend to maximise nutrient absorption before leaf fall (Haridasan, 2000), and there are strong differences between living and dead leaf traits (Delitti, 1998). Nevertheless, we expected dead leaf traits to be also unrelated to functional diversity, since there is a widespread occurrence of synergistic and antagonistic patterns during decay of leaf litter (Gartner and Cardon, 2004; Gessner, 2010).

Aluminium presented a negative effect on decomposition rates, whereas phosphorus presented a positive one. Low levels of aluminium and high levels of phosphorus indicate productive soils, which may favour detritivore and decomposers. Since these variables presented a weak explanatory power, they may not influence decomposition directly, but via other biotic components that affect nutrient cycling. For example, detritivore and decomposer subsystems play an important role in decomposition process, and differences between above- and below-ground processes affect community functioning (Hooper et al., 2002; Naeen, 2002; Spehn, 2005). Functional dissimilarity among detritivores drives community compositional effects on leaf litter mass loss (Heemsbergen et al., 2004; Srivastava et al., 2009; Zimmer et al., 2005). We expected functional diversity of woody plants to be a determining factor in detritivore activity by altering the microenvironment. However, abiotic conditions, such as aluminium and phosphorus levels in soil, might be more tightly coupled to decomposer activity than to plant diversity, contrary to our expectations.

The choice of traits is the most important step for calculating functional diversity. We must consider all traits related to the process under study and exclude traits that are functionally uninformative (Petchey and Gaston, 2006). The cerrado tends to occur on well-drained, acid, and nutrient-poor soils, with high levels of exchangeable aluminium (Goodland and Ferri, 1979). Thus, we considered traits related to resource uptake and storage, such as stem specific density, basal area, and resprouting capacity, unlike another study, which considered only leaf traits (Scherer- 
Lorenzen, 2008). The inclusion of these non-leaf traits was not masking the relation, because we did not find significant relationships between traits and decomposition rates even when we considered each trait separately. Therefore, in the cerrado and on a fine scale, both leaf and non-leaf traits were not related to community functioning.

Our study was developed on a fine scale, which may reveal greater detail about the biological mechanisms underlying patterns, but generalisations are more likely to emerge on larger scales (Wiens, 1989). For example, on a local scale, properties of the litter and the decomposers explain most of the variation in the litter decomposition rate (Ferrari, 1999). Otherwise, on larger scales, both climatic variables and plant functional traits control it (Cornwell, 2008). The decomposition rate tends to increase from open to closed cerrado physiognomies (Cianciaruso et al., 2006; Valenti et al., 2008). If species occurring in different physiognomies present different traits, we may expect the functional diversity and decomposition rate to be correlated on a regional scale. Therefore, even if functional diversity was not a predictor of community functioning in the studied cerrado on a fine scale, it is possible that it predicts community functioning on larger scales.

Most studies on the relationships between biodiversity and community functioning have been carried out in temperate regions (Cornelissen and Thompson, 1997; Fortunel, 2009; Hector et al., 2000; Knops et al., 2001; Scherer-Lorenzen, 2008; Scherer-Lorenzen et al., 2003, 2007; Spehn, 2000). Moreover, on a fine scale, only studies by experimental manipulation of diversity were developed (Hector and Loreau, 2005; Knops et al., 2001; Scherer-Lorenzen, 2008; Scherer-Lorenzen et al., 2003; 2007; Spehn, 2000). Manipulative experiments allow controlling variation in environmental conditions (Hector and Loreau, 2005), but tend to oversimplify the processes. We developed this study in a tropical savanna, on a fine scale, as a mensurative experiment (Krebs, 1999). Our findings indicated that the relationship between biodiversity and community functioning is not as straightforward, as usually assumed. Plant functional diversity may reduce the success of invasive species (Dukes, 2001) and promote heterogeneity in vertebrate habitats (Price et al., 2010). Moreover, detritivore functional diversity may affect decomposition (Heemsbergen et al., 2004). However, we did not find a relationship between functional diversity and community functioning. Thus, we can postulate that certain processes in community functioning present no relationship with certain biodiversity components, such as functional diversity of woody species and the decomposition rate. Further studies should focus on answering to which processes biodiversity components are linked and distinguish patterns that act on local and regional scales.

Acknowlegments - We are grateful to Fapesp and to CNPq for financial support and for the scholarship granted to the first author, and to R. C. Miatto, D. M. Silva and N. B. Rosatti for the valuable help in field.

\section{References}

BURNHAM, KP. and ANDERSON, DR., 2002. Model Selection and Multimodel Inference: A practical information-theoretic approach. 2nd ed. New York: Springer.

CIANCIARUSO, MV., PIRES, JSR., DELITTI, WCB. and SILVA, FP., 2006. Produção de serapilheira e decomposição do material foliar em um cerradão da Estação Ecológica de Jataí, Luiz Antônio, SP. Acta Botânica Brasilica, vol. 20, no. 1, p. 49-59.

CORNELISSEN, JHC., LAVOREL, S., GARNIEL, E., DÍAZ, S., BUCHMANN, N., GURVICH, DE., REICH, PB., STEEGE, H., MORGAN, HD., HEIJDEN, MGA., VAN DER PAUSAS, JG. and POORTER, H., 2003. A handbook of protocols for standardised and easy measurement of plant functional traits worldwide. Australian Journal of Botany, vol. 51, p. 335-380.

CORNELISSEN, JHC. and THOMPSON, K., 1997. Functional leaf attributes predict litter decomposition rate in herbaceous plants. New Phytologist, vol. 135, no. 1, p. 109-114. http://dx.doi. org/10.1046/j.1469-8137.1997.00628.x

CORNWELL, WK., CORNELISSEN, JHC., AMATANGELO, K., DORREPAAL, E., EVINER, VT., GODOY, O., HOBBIE, SE., HOORENS, B., KUROKAWA, H., PÉREZ-HARGUINDEGUY, N., QUESTED, HM., SANTIAGO, LS., WARDLE, DA., WRIGHT, IJ., AERTS, R., ALLISON, SD., BODEGOM, PV., BROVKIN, V., CHATAIN, A., CALLAGHAN, TV., DÍAZ, S., GARNIER, E., GURVICH, DE., KAZAKOU, E., KLEIN, J., READ, J., REICH, PB., SOUDZILOVSKAIA, NA., VAIERETTI, MV. and WESTOBY, M., 2008. Plant species traits are the predominant control on litter decomposition rates within biomxes worldwide. Ecology Letters, vol. 11, no. 10, p. 1065-1071. PMid:18627410. http://dx.doi.org/10.1111/j.1461-0248.2008.01219

DELITTI, WBC., 1998. Ciclagem de nutrientes em cerrados. In Anais do VIII Seminário Regional de Ecologia, 1998. São Carlos: UFSCar. p. 1031-1045.

DENYER, JL., HARTLEY, SE. and JOHN, EA., 2010. Both bottom-up and top-down processes contribute to plant diversity maintenance in an edaphically heterogeneous ecosystem. Journal of Ecology, vol. 98, no. 2, p. 498-508. http://dx.doi.org/10.1111/ j.1365-2745.2009.01633.x

DÍAZ, S. and CABIDO, M., 2001. Vive la différence: plant functional diversity matters to ecosystem processes. Trends in Ecology and Evolution, vol. 16, no. 3, p. 646-655.

DANTAS, VL. and BATALHA, MA., 2011. Vegetation structure: fine scale relationships with soil in a cerrado site. Flora, vol. 206, p. 341-346. http://dx.doi.org/10.1016/j.flora.2010.11.003

DUKES, JS., 2001. Biodiversity and invasibility in grassland microcosms. Oecologia, vol. 126, p. 563-568. http://dx.doi. org/10.1007/s004420000549

FERRARI, JB., 1999. Fine-scale patterns of leaf litterfall and nitrogen cycling in an old-growth forest. Canadian Journal of Forest Research, vol. 29, no. 3, p. 291-302. http://dx.doi. org/10.1139/x98-198

FORTUNEL, C., GARNIER, E., JOFFRE, R., KAZAKOU, E., QUESTED, H., GRIGULIS, K., LAVOREL, S., ANSQUER, P., CASTRO, H., CRUZ, P., DOEZAL, J., ERIKSSON, O., FREITAS, H., GOLODETS, C., JOUANY, C., KIGEL, J., KLEYER, M., LEHSTEN, V., LEPS, J., MEIER, T., PAKEMAN, R., PAPADIMITRIOU, M., PAPANASTASIS, VP., TIER, FQ., ROBSON, M., STERNBERG, M., THEAU, JP., BAULT, ALT. 
and ZAROVALI, M., 2009. Leaf traits capture the effects of land use changes and climate on litter decomposability of grasslands across Europe. Ecology, vol. 90, no. 3, p. 598-611. PMid:19341132. http://dx.doi.org/10.1890/08-0418.1bibEm>

GARTNER, TB. and CARDON, ZG., 2004. Decomposition dynamics in mixed-species leaf litter. Oikos, vol. 104, no. 2, p. 230-246. http://dx.doi.org/10.1111/j.0030-1299.2004.12738.x

GESSNER, MO., SWAN, CM., DANG, CK., McKIE, BG., BARDGETT, RD., WALL, DH. and HATTENSCHWILER S., 2010. Diversity meets decomposition. Trends in Ecology and Evolution, vol. 25, no. 6, p. 373-380.

GOODLAND, R. and POLLARD, R., 1973. The Brazilian cerrado vegetation: a fertility gradient. Journal of Ecology, vol. 61, p. 219-224. http://dx.doi.org/10.2307/2258929

GOODLAND, R. and FERRI, MG., 1979. Ecologia do Cerrado. São Paulo: Universidade de São Paulo.

HANSEN, RA., 2000. Effects of habitat complexity and composition on a diverse litter microarthropod assemblage. Ecology, vol. 8, no. 4 , p. $1120-1132$.

HARIDASAN, M., 2000. Nutrição mineral de plantas nativas do cerrado. Revista Brasileira de Fisiologia Vegetal, vol. 12, no. 1 , p. $54-64$

HECTOR, A., BEALE, AJ., MINNS, A., OTWAY, SJ. and LAWTON, JH., 2000. Consequences of the reduction of plant diversity for litter decomposition: effects through litter quality and microenvironment. Oikos, vol. 90, no. 2, p. 357-371. http:// dx.doi.org/10.1034/j.1600-0706.2000.900217.x

HECTOR, A. and LOREAU, M., 2005. Relationships between biodiversity and production in grasslands at local and regional scales. In McGILLOWAY, DA. (Ed.). Grassland: a global resource. Dublin. p. 295-304.

HEEMSBERGEN, DA., BERG, MP., LOREAU, M., VAN HAL, JR., FABER, JH. and VERHOEF, HA., 2004. Biodiversity effects on soil processes explained by interspecific functional dissimilarity. Science, vol. 306, no. 5698, p. 1019-1020. PMid:15528441. http:// dx.doi.org/10.1126/science.1101865

HOOPER, DU., CHAPIN, FS., HECTOR, A., INCHAUSTI, P., LAVOREL, S., LAWTON, JH., LODGE, DM., LOREAU, M., NAEEN, S., SCHMID, B., SETA, LA., SYMSTAD, AJ., VANDERMEER, J. and WARDLE, DA., 2005. Effects of biodiversity on ecosystem functioning: a consensus of current knowledge. Ecological Monographs, vol. 75, no. 1, p. 3-35. http:// dx.doi.org/10.1890/04-0922

HOOPER, DU., SOLAN, M., SYMSTADA, AJ., DIAZ, S., GESSNER, MO. and BUCHMANN, N., 2002. Species diversity functional diversity and ecossystem functioning. In LOREAU, M., NAEEN, S. and INCHAUSTI, P. (Eds.). Biodiversity and ecosystems functioning: synthesis and perspectives. Oxford: Oxford University Press. p. 195-208.

KNOPS, JMH., WEDIN, D. and TILMAN, D., 2001. Biodiversity and decomposition in experimental grassland ecosystems. Oecologia, vol. 126, no. 3, p. 429-433. http://dx.doi.org/10.1007/ s004420000537

KÖPPEN, W., 1931. Grundriss der Klimakunde. Berlin: Gruyter.

KREBS, CJ., 1999. Ecological methodology. San Francisco: Benjamin Cummings.

LEIBOLD, MA., HOLYOAK, M., MOUQUET, N., AMARASEKARE, P., CHASE, JM., HOOPES, MF., HOLT,
RD. SHURIN, JB., LAW, R. TILMAN, D., LOREAU, M. and GONZALEZ, A., 2004. The metacommunity concept: a framework for multi-scale community ecology. Ecology Letters, vol. 7, no. 7, p. 601-613. http://dx.doi.org/10.1111/j.1461-0248.2004.00608.x

LOREAU, L., 1998. Biodiversity and ecosystem functioning: A mechanistic model. Ecology, vol. 95, p. 5632-5636.

LOREAU, M. and HECTOR, A., 2001. Partitioning selection and complementarity in biodiversity experiments. Nature, vol. 412, p. 72-76. PMid:11452308. http://dx.doi.org/10.1038/35083573

MacARTHUR, RH., 1972. Geographical ecology. New York: Harper \& Row.

McLAREN, JR. and TURKINGTON, R., 2010. Ecosystem properties determined by plant functional group identity. Journal of Ecology, vol. 98, no. 2, p. 459-469. http://dx.doi.org/10.1111/ j.1365-2745.2009.01630.x

McNEIL, K., NEWMAN, I. and KELLY, FJ., 1996. Testing research hypotheses with the General Linear Model. Carbondale: Southern Illinois University Press.

MADRITCH, MD. and CARDINALE, BJ., 2007. Impacts of tree species diversity on litter decomposition in northern temperate forests of Wisconsin, USA: a multi-site experiment along a latitudinal gradient. Plant and Soil, vol. 292, no. 1, p. 147-159. http://dx.doi.org/10.1007/s11104-007-9209-5

MOUCHET, MA., VILLEGER, S., MASON, NWH. and MOUILLOT, D., 2010. Functional diversity measures: an overview of their redundancy and their ability to discriminate community assembly rules. Functional Ecology, vol. 24, no. 4, p. 867-876. http://dx.doi.org/10.1111/j.1365-2435.2010.01695.x

NAEEN, S., THOMPSON, LJ., LAWLER, SP., LAWTON, JH. and WOODFIN, RM., 1994. Declining biodiversity can alter the performance of ecosystems. Nature, vol. 368, p. 734-737. http:// dx.doi.org/10.1038/368734a0

NEGRETE-YANKELEVICH, S., FRAGOSO, C., NEWTON, AC., RUSSELL, G. and HEAL, OW., 2008. Species specific characteristics of trees can determine the litter macroinvertebrate community and decomposition process below their canopies. Plant and Soil, vol. 307, no. 2, p. 83-97. http://dx.doi.org/10.1007/ s11104-008-9585-5

PETCHEY, OL. and GASTON, KJ., 2002. Functional diversity (FD), species richness and community composition. Ecology Letters, vol. 5, no. 3, p. 402-411. http://dx.doi.org/10.1046/j.14610248.2002.00339.x

-, 2006. Functional diversity: back to basics and looking forward. Ecology Letters, vol. 9, no. 3, p. 741-758. PMid:16706917.

PETCHEY, OL., HECTOR, A. and GASTON, KJ., 2004. How do different measures of functional diversity perform? Ecology, vol. 85 , no. 3, p. 847-857. http://dx.doi.org/10.1890/03-0226

PRICE, B., KUTT, AS. and McALPINE, CA., 2010. The importance of fine-scale savanna heterogeneity for reptiles and small mammals. Biological Conservation, vol. 143, no. 3, p. 2504-2513. http:// dx.doi.org/10.1016/j.biocon.2010.06.017

R Development Core Team, 2010. R: a language and environment for statistical computing. Vienna: R Foundation for Statiscal Computing. Available from: <http://www.r-project.org $>$.

RASBAND, W., 2004. ImageJ: Image process and analysis in Java. Bethesda: National Institutes of Health. 
RICOTTA, C., 2005. A note on functional diversity measures. Basic and applied Ecology, vol. 6, no. 5, p. 479-486. http://dx.doi. org/10.1016/j.baae.2005.02.008

São Paulo. Secretaria do Estado do Meio Ambiente, 1997. Cerrado: bases para conservação e uso sustentável das áreas de cerrado do estado de São Paulo. São Paulo: SMA. Série PROBIO/SP.

SCHERBER, C., HEIMANN, J., KÖHLER, G., MITSCHUNAS, N. and WEISSER, WW., 2010. Functional identity versus species richness: herbivory resistance in plant communities. Oecologia, vol. 163, no. 3, p. 707-717. PMid:20429014 PMCid:2886090. http://dx.doi.org/10.1007/s00442-010-1625-1

SCHERER-LORENZEN, M., 2008. Functional diversity affects decomposition process in experimental grasslands. Functional Ecology, vol. 22, no. 2, p. 547-555. http://dx.doi.org/10.1111/j.13652435.2008.01389.x

SCHERER-LORENZEN, M., BONILLA, J.-L. and POTVIN, C., 2007 Tree species richness affects litter production and decomposition rates in a tropical biodiversity experiment. Oikos, vol. 116, no. 6, p. 2108-2124. http://dx.doi.org/10.1111/j.2007.00301299.16065.x

SCHERER-LORENZEN, M., PALMBORG, C., PRINZ, A. and SCHULZE, ED., 2003. The role of plant diversity and composition for nitrate leaching in grasslands. Ecology, vol. 84, no. 6, p. 1539-1552. http://dx.doi.org/10.1890/0012-9658(2003)084[1539:TROPDA ]2.0.CO;2

SEASTADT, TR., 1984. The role of microarthropods in decomposition and mineralisation process. Annual Review Entomology, vol. 29, p. 25-46. http://dx.doi.org/10.1146/annurev. en.29.010184.000325

SOUZA, AF. and MARTINS, FR., 2004. Microsite specialization and spatial distribution of Geonoma brevispata, a clonal palm in south-eastern Brazil. Ecoogical Research, vol. 19, no. 5, p. 521-532. http://dx.doi.org/10.1111/j.1440-1703.2004.00670.x

SPEHN, E.M., JOSHI, J., ALPHEI, J., SCHMID, B. and KÖRNER, C., 2000. Plant diversity effects on soil heterotrophic activity in experimental grassland ecosystems. Plant and Soil, vol. 224, no. 2, p. 217-230. http://dx.doi.org/10.1023/A:1004891807664

SRIVASTAVA, DS., CARDINALE, BJ., DOWNING, AM., DUFFY, JE., JOUSEAU, C., SANKARAN, M. and WRIGHT, JP., 2009. Diversity has stronger top-down than bottom-up effects on decomposition. Ecology, vol. 90, no. 4, p. 1073-1083. PMid:19449701. http://dx.doi.org/10.1890/08-0439.1

SWIFT, MJ., HEAL, OW. and ANDERSON, JM., 1979. Decomposition in Terrestrial Ecossystem. Oxford: Blackwell.

TILMAN, D., KNOPS, J., WEDIN, D., REICH, P., RITCHIE, M. and SIEMANN, E., 1997. The influence of functional diversity and composition on ecosystem processes. Science, vol. 277, p. 1300-1302. http://dx.doi.org/10.1126/science.277.5330.1300

VALENTI, MW., CIANCIARUSO, MV . and BATALHA, MA., 2008. Seasonality of litterfall and leaf decomposition in a cerrado site. Brazilian Journal of Biology, vol. 68, no. 3, p. 459465. http://dx.doi.org/10.1590/S1519-69842008000300002

VIVANCO, L. and AUSTIN, AT., 2008. Tree species identity alters forest litter decomposition through long-term plant and soil interactions in Patagonia, Argentina. Journal of Ecology, vol. 96, no. 4, p. 727-736. http://dx.doi.org/10.1111/j.13652745.2008.01393.x

WIEDER, RK. and LANG, CE., 1982. A critique of the analytical methods used in examining decomposition data obtained from litter bags. Ecology, vol. 63, no. 6, p. 1636-1642. http://dx.doi. org/10.2307/1940104

WIENS, JA., 1989. Spatial Scaling in Ecology. Functional Ecology, vol. 3, no. 4, p. 385-397. http://dx.doi.org/10.2307/2389612

ZIMMER, M., KAUTZ, G. and TOPP, W., 2005. Do woodlice and earthworms interact synergistically in leaf litter decomposition? Functional Ecology, vol. 19, p. 7-16. http://dx.doi.org/10.1111/ j.0269-8463.2005.00926.x 